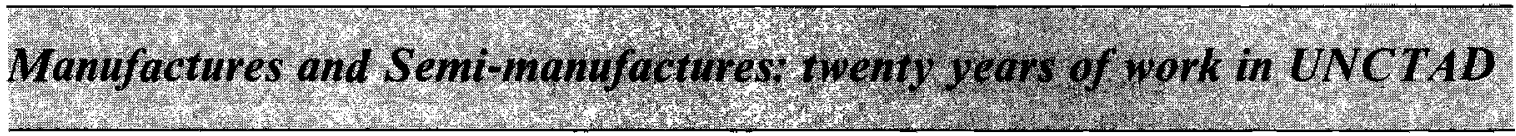

\title{
Colin Greenhill
}

All the countries represented at the first session of the Conference in 1964 recognised the need for the diversification and expansion of developing countries' export trade, especially in the area of manufactures and semi-manufactures. This was seen as a means of accelerating development and raising living standards, as envisaged in the objectives of the First United Nations Development Decade strategy, and narrowing, as rapidly as possible, the commercial deficit resulting from the trends in international trade current at that time. In its final recommendations the Conference emphasised the need to create conditions which would promote the establishment of export-oriented production in developing countries and encourage diversification and expansion of trade, in particular through the liberalisation of tariff and non-tariff barriers in developed countries, the provision of financial and technical assistance, and closer economic cooperation amongst developing countries. ${ }^{\prime}$

In terms of practical, concrete measures, preferences in favour of developing countries were seen by all the developing countries, and the great majority of developed countries, as a key means of assisting the former's industrial growth. Hence, the Conference called for the establishment of a committee to work out the best method of implementation on the basis of non-reciprocity from developing countries, as well as to discuss further remaining differences of principle.

\section{Granting of Preferences to Developing Countries}

During the following four years considerable headway was made in the narrowing of differences between countries on the issue of preferences, and this was reflected in the submissions to the second session of the Conference by both the developing and the developed market-economy countries. In the Charter of Algiers, adopted at the Ministerial Meeting of the Group of 77 in October 1967, the developing countries

\footnotetext{
See, in this connection, Annex A.I11.3, A.1II.4, A.III.5, A.III.6, A.III.7, A.III.8 of the Final Act.
}

set out principles which they considered should be observed in the Generalised System of Preferences. A report by the Secretary-General of the OECD on 'Problems and policies of trade in manufactures and semi-manufactures' recognised the case for temporary special tariff treatment by developed countries in favour of developing countries. In consequence, at its second session, the issue of preferences was at the centre of the negotiations. As a result, the Conference unanimously agreed to the early establishment of a mutually acceptable system of generalised, nonreciprocal and non-discriminatory preferences which would be beneficial to the developing countries, setting out the objectives of the system in resolution 21(II). A time table was established to settle the details of the preferential arrangements and a Special Committee on Preferences was established to conduct the necessary negotiations

During the next two years intensive negotiations in the Special Committee led to the elaboration of the Generalised System of Preferences (GSP), with agreed conclusions being adopted in October 1970. This involved consultations on the preliminary offers of the prospective preference-giving countries for improved access to their markets. The agreed conclusions defined the technical, institutional and legal aspects of the system. In addition, the Special Committee welcomed the joint declaration of several socialist countries of Eastern Europe announcing the measures which these countries intended to take to promote the exports, industrialisation and growth of the developing countries, in fulfilment of the objectives in Conference resolution 21 (II). These measures consisted of tariff preferences in the case of countries having a custom tariff, and of other special measures of a preferential nature designed to expand imports from developing countries

At its fourth special session, held in October 1970, the Trade and Development Board took note of the agreed conclusions of the Special Committee and, by their decision of June 1971, the Contracting Parties to 
the GATT decided to waive the provisions of Article I of the General Agreement for a period of 10 years to the extent necessary to permit developed contracting parties to accord preferential treatment to products originating in developing countries and territories. ${ }^{2}$

In the negotiations leading to the adoption of the GSP, the developed countries were guided by the principle of equal 'burden sharing', leaving it to each country to determine the scope and details of each scheme. The result of this was that the GSP, as implemented, now consists of 16 separate schemes introduced between 1965 and $1974 .^{3}$

The nature of the GSP has been largely determined by the manner in which preference-giving countries interpret the principles of generalised non-discriminatory and non-reciprocal preferences on which the system is based. The concept of generalised preferences implied that preferences would be granted by all developed countries to all developing countries. Non-discrimination implied that the same preferences would be granted to all developing countries. The absence of an agreed definition of developing countries created initial difficulties. It was eventually agreed that the principle of self-election would be followed, namely, preferences would be granted to any country or territory claiming developing status, with individual preference-giving countries retaining the right to decline to accord such preferences on grounds which they held to be compelling, provided that this was not based upon competitive considerations. As a result, each preference-giving country has its own particular list of beneficiaries.

The third principle of non-reciprocity is what makes the GSP stand out as a landmark in trade relations between developed and developing countries. For the first time, developed countries agreed to make tariff concessions without seeking reciprocity. The impact of this change in attitude extended beyond the GSP and was particularly evident in the negotiation of the EEC-ACP Lomé Convention which also provides for non-reciprocity. Moreover, it is reflected in many of the codes negotiated during the Tokyo Round which

\footnotetext{
2 Decision of 25 June 1971 -... see GATT Basic Instruments and Selected Documents, 18th supplement, page 24 .

3 Australia, which had been applying a system of tariff preferences in favour of developing countries prior to the adoption of the GSP. implemented a new and substantially broader scheme on 1 January 1974. Similarly, the USSR, following the first session of UNCTAD. implemented as from 1 January 1965 , its scheme of preferences. The other countries or groups of countries providing preferences and the dates of entry into force of their schemes are: Austria. I April 1972; Bulgaria. 1 April 1972: Canada. 1 July 1974: Czechoslovakia. 28 February 1972: EEC, 1 July 1971: Finland. 1 January 1972: Hungary. I January 1972: Japan. 1 August 1971: New Zealand. 1 January 1972: Norway. 1 Oetober 1971: Poland. 1 January 1976; Sweden. I January 1972: Switzerland. 1 March 1972: United States. 1 January 1976.
}

provide for differential and more favourable treatment for developing countries, as well as in the Set of Multilaterally Agreed Equitable Principles and Rules, which is the subject of the following section.

Since the introduction of the schemes most of the preference-giving countries have substantially extended their list of beneficiaries. This has constituted one of the main improvements in the System. In most schemes de veloping country members of the Group of 77 are recognised as beneficiaries. In this context it should be noted that the list of beneficiaries of the US scheme gave rise to the greatest controversy because a number of developing countries were excluded, in particular members of OPEC, on the basis of certain criteria specified in United States legislation. Conditions on eligibility for preferential treatment were also applied inter alia by Japan and Canada, the latter on the basis of whether the countries were entitled to most favoured nation treatment. ${ }^{4}$

In general, the GSP covers all manufactured and semimanufactured products, the main exceptions being textiles, leather and petroleum products. In contrast to the broad coverage on industrial products, the GSP covers only selected agricultural products and the coverage varies from one scheme to another. Product coverage in this sector has been improved during the life of the schemes, with the addition, as a result of the Tokyo Round, of a number of tropical products.

The extent of the tariff preference granted varies from scheme to scheme, though, for most industrial products, the major trading countries grant duty-free treatment. Where this has not been granted there have, during the life of the schemes, been improvements in the depth of tariff cuts.

Generally, all schemes contain escape clause provisions whereby the preference-giving country reserves the right to withdraw, in whole or in part, the preferential tariff treatment when the product in question is imported in such increased quantity as to cause, or threaten to cause, serious injury to domestic producers of like or directly competitive products. In addition, the schemes contain a number of a priori limitations in the form of tariff quotas, tariff ceilings, for example in the EEC and Japan, or the exclusion of individual beneficiaries from preferential treatment with respect to particular products when they are considered to be competitive, for example the US.

The General Assembly included the GSP as an integral part of the International Development

\footnotetext{
4 Other countries or territories receiving preferences in one or more schemes are: Albania, Brunei. Bulgaria. China. Kiribati. Israel. Mongolia. Muscat. Nauru. Portugal. Spain, Turkey. Hong Kong, Macao. Timor and Taiwan. Province of China.
} 
Strategy for both the Second and Third United Nations Development Decades, and it is an important element of the Programme of Action on the establishment of a New International Economic Order and of the Charter of Economic Rights and Duties of States. It was also considered an important instrument in achieving the objectives of the Lima Declaration and Programme of Action on industrial collaboration and cooperation. In Belgrade, in 1983, the Conference at its sixth session called for continued improvements in the schemes and requested the Trade and Development Board to study the operation of the system in order to assess its stability and effectiveness.

\section{Restrictive Business Practices}

Governments have long recognised that restrictive business practices (RBPs) required action at the international level, and the first efforts to seek international agreement were made at the time of the drawing up of the Havana Charter in 1947-48. This contained a chapter on the subject which was never brought in to effect, mainly because, up until that time, virtually only Canada and the United States had legislation in this field. However, in the 1950s and $1960 \mathrm{~s}$ most other developed market-economy countries, including Japan and the EEC, introduced relevant legislation, and during the course of the $1960 \mathrm{~s}$ and 1970s a number of developing countries followed suit, including Argentina, Brazil, Chile, India, Pakistan, Republic of Korea, Sri Lanka, Thailand, Yugoslavia, and some socialist countries of Eastern Europe. While the motive in developed countries for the introduction of such legislation was primarily to maintain competition, in developing countries it seems to have been to control the structure of economic power and to protect consumers.

Concern about the power exercised by developed countries' enterprises in domestic and international markets, and in particular their increasing use of RBPs to maintain and strengthen that power in response to the emergence of increased competition from new entrants, led developing countries to press for international action in this area at the second session of the Conference. A tentative start was made as a result of Conference resolution 25(II), adopted by rollcall vote, with most developed market-economy countries either opposing or abstaining. It called for a study of the RBPs adopted by private enterprises of developed countries, with special reference to their effects on the export interests of developing countries, especially the least developed among them. This was followed in 1970 by the call in the International Development Strategy for the Second United Nations Development Decade for the identification of RBPs, particularly those affecting the trade and development of developing countries, with a view to considering appropriate remedial measures - the aim being to achieve significant results early in the decade.

In the light of the detailed studies undertaken and the work in the Committee on Manufactures, the third session of the Conference in 1972 recommended that guidelines be drawn up for consideration by governments of both developed and developing countries regarding RBPs affecting developing countries. A group of experts was duly appointed in their personal capacity to identify the practices in question and to examine the possibility of drawing up guidelines. Following the successful work of this group, the Committee on Manufactures decided, in resolution 9(VII), that an intergovernmental group of experts should be established to examine the possibility of formulating multilaterally accepted principles. Shortly after this, the General Assembly, at its Seventh Special Session, decided in the context of the establishment of the New International Economic Order, that RBPs adversely affecting international trade, particularly that of developing countries, should be eliminated and that efforts should be made at national and international levels to negotiate a set of equitable principles and rules. ${ }^{5}$

Thus, at its fourth session in May 1976, the Conference had before it the work of two Expert Groups, as well as the goals set by the General Assembly for action in this area. The Conference, in section III of resolution 96(IV), accordingly agreed that action should be taken in a mutually reinforcing manner at national, regional and international levels, to eliminate or deal effectively with RBPs, including those of transnational corporations, adversely affecting international trade and economic development. In this context, it specifically decided that action at the international level should include negotiations with the objective of formulating a set of multilaterally agreed equitable principles and rules. To facilitate the achievement of this and other agreed action, the Conference established the Third ad hoc Group of Experts on Restrictive Business Practices and called upon it to prepare detailed proposals and recommendations.

After four years the Expert Group came up with a fairly complete text of what might emerge as an agreed international instrument. Taking into account the significant progress made, the General Assembly decided - upon the recommendation of the Trade and Development Board in resolution 33/153 of December 1978 - to convene, under the auspices of UNCTAD, the United Nations Conference on Restrictive Business Practices, which met in November/ December 1979. It reconvened in April 1980, when it concluded its work by drafting the Set of Multilaterally Agreed Equitable Principles and Rules for the Control

\footnotetext{
${ }^{5}$ G.A./Res/3362 (S-VII), section $\mathrm{I}$, paragraph 10 .
} 
of Restrictive Business Practices. This ${ }^{6}$ was transmitted to the General Assembly and unanimously adopted by it at its thirty-fifth session in December 1980 by resolution 35/63. In so doing states undertook a morally binding commitment to take appropriate steps at national or regional levels to meet their commitment to the Set of Principles and Rules. Moreover, in dra wing up the Set, states expressed their conviction of the benefits to be derived from such a universally applicable Set of Principles and Rules and stated that all countries should encourage their enterprises to follow, in all respects, the provisions of the Set (preambular paragraph 6). The Set specifies the principles and rules both for enterprises, including transnational corporations, and for states. A wide range of practices is proscribed for enterprises when they limit access to markets, or otherwise unduly restrain competition, having or likely to have adverse effects on international trade, particularly that of developing countries and their economic development.

As a result of the adoption of the Set of Principles and Rules the Intergovernmental Group of Experts on Restrictive Business Practices was established by the Trade and Development Board and assigned the task of monitoring the application and implementation of the Set. In addition, the General Assembly decided to convene, in 1985, a United Nations Conference to review all aspects of the Set, and called upon the Intergovernmental Group of Experts to make proposals to the Conference for their improvement and further development.

Since the adoption of the Set, the Intergovernmental Group has held two sessions. In reviewing the action taken, the Group, at both sessions, expressed its concern about the persistent resort to the use of restrictive business practices in international trade transactions, and stressed the need for countries to institute effective controls. Action taken by states has consisted essentially in the disse mination of the text of the Set to enterprises and to the public at large and, where necessary, the translation of the Set into national languages. A number of developing and developed countries have enacted legislation and others are contemplating new or amended laws on restrictive business practices. The Set has been invoked in Norway in a case of refusal to deal by a foreign supplier, and cooperation has been established among certain member states regarding the collection of information on restrictive business practices, particularly in the Nordic countries and the Asian and Oceanic regions.

\footnotetext{
6 The Set of Multilaterally Agreed Equitable Principles and Rules for the Control of Restrictive Business Practices (TD/RBP/CONF/ 10/Rev.1).
}

The Set of Principles and Rules is a decisive first step in international efforts to control restrictive business practices. In a sense it can be seen as completing the work initiated at the time of the Havana Charter.

\section{The Crisis of Confidence in the International Trading System}

Aside from actions to improve trading conditions through the Generalised System of Preferences and the control of restrictive business practices were the multilateral trade negotiations conducted in the context of the Kennedy and Tokyo Rounds. In the latter Round in particular, while not directly involved in the negotiations, UNCTAD provided, through its work in the Committee on Manufactures and the decisions taken at the third and fourth sessions of the Conference, ${ }^{7}$ an impetus to them by laying stress on aspects of particular concern and interest to developing countries, for example, liberalisation for tropical products. In addition, technical assistance was provided to help developing countries participate in the negotiations.

Ironically, while the successive rounds of multilateral trade negotiations resulted in a substantial lowering of tariffs - and by the same token in a certain whittling down of the tariff concessions granted under the GSP - there occurred a major change in international trade relations generally which resulted in a crisis of confidence in the operation of the trading system.

To an important extent this crisis arose from the very success of the efforts made by Japan and developing countries to expand and diversify their production and exports, and from the challenges this posed to traditional producers in the developed marketeconomy countries, not only in terms of supplies to domestic markets but also internationally. On the one hand, developed countries resisted the full extent of the structural adjustments required, as reflected in their loss of comparative advantage, and on the other hand, they were reluctant to accept that developing countries have become important trading partners during the past 20 years, and can no longer be excluded from, or taken for granted in, decisions regarding the operation of the trading system.

During the 1970s and 1980s, the developing countries acted as a buffer to the severity of the recession by providing export opportunities in their markets when demand severely contracted in developed countries. On the other hand, developing countries and Japan were forced to accept restraints on their own exports. In this regard the position taken by Japan has been crucial. Its acceptance of voluntary export restraints or targets for controlling its exports to the EEC and

\footnotetext{
7 See in this context Conference resolutions $76(111)$ and $96(\mathrm{IV})$.
} 
the US - beginning with the short-term arrangement on cotton textiles - led to trade in an increasing number of sectors, especially textiles and clothing, steel, shipbuilding, motor vehicles and electronic products, being controlled outside the framework of the General Agreement. This involved not only government to government actions but in Europe particularly, industry arrangements at both national and international levels concerning restrictive business practices.

The difficulties encountered in the negotiations on an improved safeguard arrangement in the Tokyo Round, which have persisted in the subsequent negotiations on a comprehensive understanding on an improved and more effective safeguard system, reflect to an important extent the unwillingness or inability of the major trading partners to tackle the structural adjustment issue and, as a corollary, the development needs of developing countries. In previous rounds of multilateral trade negotiations it had been possible for the major trading countries to negotiate agreements and to present them as a fait accompli to smaller trading partners. The 1980 s have seen a change in this situation. In part, one can see demands for reciprocity from developing countries and unilateral decisions to graduate certain of them from the GSP as attempts to retrieve perceived loss of bargaining power by the major trading countries. On the other hand, acceptance of the increased importance of developing countries as trading partners is also evident in the pressure being brought on them to participate in the work desired by some major trading countries in the GATT on services. Parenthetically, developing countries account for a large portion of developed countries' export of services (service credits) as evidenced by the fact that over 90 per cent of world trade in consulting engineering services takes the form of exports to developing countries, and over 80 per cent in the case of construction and project management.

Discontent with the pace of structural change led developing countries to press at the fifth session of the Conference for strengthened commitments by developed countries to remove protectionism and adopt positive structural adjustment policies. As a result the Conference, in resolution $131(\mathrm{~V})$, called upon the Trade and Development Board to organise an annual review of production and trade patterns in the world economy and to continue to review developments in trade restrictions with a view to formulating recommendations on protectionism.

Between the fifth and sixth sessions of the Conference, the Trade and Development Board, in undertaking these reviews, laid stress on the need for a comprehensive approach to the issues involved with commensurate treatment being given to all sectors, namely agriculture, manufactures and services. ${ }^{\gamma}$ In addition, during its regular sessions, the Trade and Development Board considered developments in the international trading system, in particular as a result of the implementation of the agreements negotiated in the Tokyo Round.

The sixth session of the Conference met against the background of a crisis in international trade and in the operation of the trading system. It is within this context that the adoption of Conference resolution 159 (VI) on international trade issues must be viewed. It called upon the Trade and Development Board in its annual reviews to monitor the implementation of the commitments made to halt and roll back protectionism and to provide differential and more favourable treatment to developing countries. It also called upon the Trade and Development Board to review and monitor trade developments and, where appropriate, to make general policy recommendations and review progress on structural adjustment. Another important step taken by the Conference was its decision that the Trade and Development Board should study in-depth developments in the international trading system. This would be done as a prelude to making recommendations on the principles and policies related to international trade and to formulating proposals for strengthening and improving the trading syste $\mathrm{m}$, both to give it a more universal and dyna mic character, and to make it more responsive to the needs of developing countries and conducive to their accelerated growth and development. The Conference also laid stress on the need for further work in UNCTAD on trade in services, and entrusted the Board at its twenty-ninth session in 1984 to consider appropriate future work.

\section{Conclusion}

During the 20 years of UNCTAD's existence, there have clearly been not only important changes in respect of trade in manufactures and semi-manufactures, but also an evolution in the policy framework. The two instruments negotiated on the Generalised System of Preferences and restrictive business practices have not been limited to manufactures and semi-manufactures, but also embraced agricultural goods and, in the case of restrictive business practices, services. It was therefore logical and appropriate that, in tackling the issues of protectionism and structural adjustment, the Trade and Development Board and the Conference have focused on trade policies generally and, while paying particular attention to the needs of the developing countries, have sought a comprehensive approach to trade problems generally, including those of a systemic nature.

\footnotetext{
* Decision 250 (XXIV).
} 